\title{
The Impact of Energy Consumption and Agricultural Production on Carbon Dioxide Emissions in Portugal
}

\author{
Nuno Carlos Leitão ${ }^{1}$, Jeremiás Máté Balogh ${ }^{2}$ \\ ${ }^{1}$ Polytechnic Institute of Santarém, CEFAGE, Évora University, Portugal \\ ${ }^{2}$ Corvinus University of Budapest, Hungary
}

\begin{abstract}
The consequences of climate change heavily influence the Mediterranean region. However, the Portuguese $\mathrm{CO}_{2}$ emission shows a decreasing tendency, the evolution of livestock and animal production have significantly increased its level in agriculture. The article investigates the role of the agricultural output and energy consumption in the environmental pollution in Portugal. It explores the short and long-run cointegration between carbon dioxide emissions and agricultural activities such as crop production, livestock production, and agricultural land use applying Autoregressive Distributed Lag (ARDL), Granger causality, Newey-West Standard Errors regression, as well as ARIMA model for the period of 1960-2015. The causality relation between $\mathrm{CO}_{2}$ emissions and agriculture is also analyzed. The Augmented Dickey-Fuller (ADF) unit root tests suggest that all variables are stationary. ARDL model demonstrates a long-run relationship between $\mathrm{CO}_{2}$ emissions, agriculture, and energy consumption. Results indicate that agricultural activities and energy use have a positive effect on environmental pollution; therefore, the Portuguese agriculture needs to achieve a higher level of sustainable development, with reducing the impact of animal husbandry and intensive crop production.
\end{abstract}

\section{Keywords}

Climate change, carbon dioxide emissions, agricultural production, time series, Portugal.

Leitão, N. C. and Balogh, J. M. (2020) "The Impact of Energy Consumption and Agricultural Production on Carbon Dioxide Emissions in Portugal ", AGRIS on-line Papers in Economics and Informatics, Vol. 12, No. 1, pp. 49-59. ISSN 1804-1930. DOI 10.7160/aol.2020.120105.

\section{Introduction}

In the last decades, climate change and global warming have been becoming an urgent issue for policy and decision makers.

Ritchie (2017) suggest that livestock takes up nearly $80 \%$ of global agricultural land yet produces less than $20 \%$ of the world's supply of calories. Economic development exerts an increasing impact on land resources. Furthermore, the world population uses approximately 50 percent of the total habitable land for agriculture.

The Mediterranean region is predicted to suffer from increasingly severe droughts in the future due to climate changes, in addition to increased problems with soil salinity and increased temperatures (Jacobsen et al., 2012).

Portugal managed to fulfill its Kyoto Target for the period 2008-2012. In contrast, it reached $16 \%$ higher level of emissions in 2011 compared to 1990 (PIA, 2013). In 2017, the Portuguese
$\mathrm{CO}_{2}$ emission was $4 \%$ lower compared to 2000 (Statista, 2018) showing a decreasing tendency. However, the projected energy-related carbon dioxide emissions of Portugal might significantly decrease for 2050, the level of non-energy non-land use related emission remain relatively high.

Besides, recent statistics suggest that environmental pollution cause a serious problem in Portugal. Torres et al. (2018) revealed that Lisbon and its surroundings are the most critical areas of emissions.

Mourão and Martinho (2017) researched the externalities of agricultural activities related to greenhouse gas emissions for Portugal by analyzing data gathered since 1961. They concluded that the evolution of the output levels of livestock and the most representative animal production have significantly increased the level of $\mathrm{CO}_{2}$ in the country.

Ministerial conferences such as Kyoto Protocol (1997) and Paris Agreement (2015) stimulated 
the empirical research on climate change using econometric tools applied on time series or panel data.

According to recent empirical studies, agriculture is responsible for approximately one-third of the greenhouse gas emission in the world. In other words, climate change has become a global concern stimulating the interest of the academic community. Recent articles (Balogh and Jámbor, 2017; Hongdou et al., 2018; and Appiah et al., 2018) demonstrate that agricultural production is directly correlated with climate change. In this context, we present relevant empirical literature investigating the agriculture-specific factors (crop production, livestock production, and agricultural land) on environmental pollution.

In recent years, econometric studies (Shahbaz et al., 2013; Shahbaz et al., 2015; Leitão, 2015; Balogh and Jámbor, 2017; Hongdou et al., 2018; and Appiah et al., 2018) have used energy consumption, renewable energy, income per capita, foreign investment, international trade, and agricultural production as independent variables modelling the determinates of climate change.

Many studies have focused on the assessment of climate change based on the assumptions of the Kuznets environmental curve (Shahbaz et al., 2015; Mahmood et al., 2017; Och, 2017). Another category of studies evaluated the direct impact of agricultural productivity on $\mathrm{CO}_{2}$ emissions (Mara, 2011; Edoja et al., 2016; Ullah et al., 2018; Sarkodie and Owusu, 2017; Hongdou et al., 2018; and Appiah et al., 2018). Our research follows the second line of studies and applies it to Portugal dioxide emissions.

Different econometric methods have been used to analyze the agricultural activity on climate change on time series (ARDL-Autoregressive Distributed Lag; VAR- Vector Autoregression, the VECM - Vector Error Correction Model, Granger's causality). In this context, Hongdou et al. (2018) studied the relationship between ecosystem and climate change applied to China for the period 1960-2014. The authors used Granger causality, cointegration, and the Vector error correction model (VECM) as econometric tools for the analysis. The results demonstrated that fertilizes are positively correlated with $\mathrm{CO}_{2}$ emissions, and crop production (rice and cereal) have a positive impact on climate change.

Sarkodie and Owusu (2017) applied unit root test, linear regression, and Autoregressive Distributed Lag (ARDL) for analyzing the environmental pollution in Ghana. Authors revealed a longrun cointegration between $\mathrm{CO}_{2}$ emissions and agricultural sectors.

Marques et al. (2018) estimated an ARDL model for meat consumption of 77 countries with different level of economic development controlling for economic growth, sustainable development, and food consumption. The authors concluded that meat consumption has a negative effect on poor economies with significant environmental costs.

The long-run causality between carbon dioxide emissions, agricultural productivity, energy consumption, and land use was researched by Khan et al. (2018) for the Pakistan case between 1981 and 2015. Researchers demonstrated a long-run causality between variables by using the Vector Error Correction Model (VECM). Granger causality revealed a bidirectional causality between agriculture productivity and forest area.

The investigation realized by Waheed et al. (2018) studied the effect of renewable energy, agricultural production, and forest area on $\mathrm{CO}_{2}$ emissions. The authors applied the ARDL model for the period 1990-2014. The results show that renewable energy and forest area negatively affect $\mathrm{CO}_{2}$ emissions in the long run, explained by a decrease of $\mathrm{CO}_{2}$ emissions. On the other hand, conversely agricultural production usually positively influences $\mathrm{CO}_{2}$ emissions. In addition, Jebli and Youssef (2017) investigated the causal long-run relationship between renewable energy and carbon dioxide emissions as well as the link between agriculture activity and $\mathrm{CO}_{2}$ emissions for the period 1980-2011. Employing a panel cointegration (OLS, FMOLS, DOLS, and Granger causality test) applied to Algeria, Egypt, Morocco, Sudan, and Tunisia, researchers confirmed bidirectional causality between agricultural activity and $\mathrm{CO} 2$ emissions.

Appiah et al. (2018) measured the effect of environmental pollution on climate change using OLS and FMOLS estimators and concluded that energy consumption is negatively correlated with $\mathrm{CO}_{2}$ emissions. By contrast, crop production, livestock production, population, and income per capita had a positive effect on climate change.

As a rule, environmental models of the Kuznets curve (EKC) or economic growth models, regularly introduce energy consumption as an explanatory variable. In this context, Kais and Mbarek (2015) evaluate the relationship between carbon dioxide emissions, energy consumption and growth for the period 1980-2012 
using panel cointegration, FMOLS, and DOLS estimators, Granger causality test, and Vector Error Correction (VECM) to Algeria, Egypt, and Tunisia. Regarding the econometric results, it is possible to infer that $\mathrm{CO}_{2}$ emissions and energy consumption are cointegrated. Similarly, Kais and Mbarek (2015) demonstrate a unidirectional causality between energy consumption, economic growth and carbon dioxide emissions in the help of VECM.

The research proposed by Tan and Tan (2018) evaluates energy consumption, economic growth and carbon dioxide emissions applied to Malaysia for the period 1980-2014 demonstrates that there is a unidirectional causality between energy consumption and $\mathrm{CO}_{2}$ emissions when the authors applied Granger causality and VECM. In this line, the study of Acheampong (2018) using a panel vector autoregression and a GMM-system reveals a positive impact of carbon dioxide emissions and energy consumption on economic growth in sub-Saharan Africa. On the one hand, the empirical results also confirm that energy consumption has a negative effect on growth in MENA countries. Moreover, a positive impact of energy consumption was suggested in MENA countries, a negative effect in Sub-Saharan Africa and Caribbean-Latin America on $\mathrm{CO}_{2}$ emissions.

The paper examines the relationship between climate change and agriculture measured by carbon dioxide emissions $\left(\mathrm{CO}_{2}\right)$, crop production index and livestock production index, agricultural land referring to the period 1960-2015 in Portugal. The role of Portuguese energy consumption is also investigated. Following the recent literature (Appiah et al., 2018; Ullah et al., 2017; Sarkodie and Owusu 2017; and Hongdou et al., 2018) we apply time series econometric techniques (Unit Root Test, Autoregressive Distributed Lag - ARDL and Granger causality) for the analysis. Furthermore, we test the existence of the long-run relationship through cointegration between environmental pollution $\left(\mathrm{CO}_{2}\right.$ emissions) and Portuguese energy consumption, crop production, livestock production and agricultural land use.

This research aims to contribute to the literature in three ways. First, it presents a literature review of recent empirical studies on climate change. Second, it estimates the short and the longrun relationship between climate change and agricultural activity in Portugal. Finally, it provides policy implication to reduce the impact of agriculture on environmental pollution in Portugal.

The article is designed as follows. Section 2 presents the materials and methods. The econometric results are illustrated in section 3 . The final section concludes.

\section{Materials and methods}

This research analyzes the Portuguese agricultural factors (crop production, livestock production, and agricultural land), and energy consumption on climate change for the period 1960-2015. The econometric models as Autoregressive Distributed Lag (ARDL) and Granger Causality tests are used in this study. We also employ the ARIMA model and Newey-West Standard Errors regression as a complementary methodology. The time series variables were collected from the World Bank (2018) and the Foodand Agriculture Organization (FAO) data.

The dependent variable is carbon dioxide emissions $\left(\mathrm{CO}_{2}\right.$ emissions), representing climate change. The explanatory variables selected in this investigation are energy consumption (EC), crop production index (Crop), livestock production index (Livestock), and agricultural land use (Land).

Based on the recent empirical works (Appiah et al., 2018; Ullah et al., 2018; Hongdou et al., 2018; and Sarkodie and Owusu, 2017) the following function is established in an equation 1:

$\mathrm{CO}_{2}=f(E C$, Crop, Livestock, Land $)$

According to equation 1, we regress the effects of agricultural production quantities on carbon dioxide emissions. Considering the model, we specify an equation 2 . All variables are presented in a logarithm form.

$$
\begin{aligned}
\operatorname{LnCO}_{2}= & \beta_{0}+\beta_{1} \text { LnEC }+\beta_{2} \text { LnCrop }+ \\
& \beta_{3} \text { LnLivestock }+\beta_{4} \text { LnLand }+u_{t}
\end{aligned}
$$

where

$\mathrm{CO}_{2}$ represents the dependent variable and is measured by carbon dioxide emissions (expressed in kilotons), collected by the World Bank.

The independent variables are the following:

$E C$ - signifies the electric power consumption ( $\mathrm{kWh}$ per capita), according to the World Bank, the explanation of this variable represents the production of power plants and their transmission. The source of this variable is the World Bank and IEA Statistics.

Crop - denotes crop production index from FAO production index and World Bank.

Livestock - represents the livestock production 
index. According to the World Bank, the description of this proxy contains meat, milk, cheese and eggs, raw silk, wool, hides, and skins. The variable is derived from the World Bank and the FAO databases.

Land - Agriculture land, i.e. according to the description of the World Bank is the arable land area, sourced by FAO and World Bank.

$u_{t}$ - captures the error term.

Based on the empirical literature, we formulate the next hypotheses for Portugal:

$H_{1}:$ There is bidirectional causality between energy consumption and $\mathrm{CO}_{2}$ emissions.

According to the literature Ozturk and Acaravci (2011), Kais and Mbarek (2015), Tan and Tan (2018) the variables of energy consumption and carbon dioxide emissions are cointegrated. Balogh and Jámbor (2017) also demonstrate that energy consumption stimulates climate change.

$H_{2}$ : Agricultural production positively associated with climate change through $\mathrm{CO}_{2}$ emission in Portugal.

Some empirical studies such as Sarkodie and Owusu (2017), Ullah et al. (2018), Hongdou et al. (2018), Khan et al. (2018) found a positive correlation between agricultural production and climate change. These studies highlight that intensive agricultural land use without sustainable practices encourages climate change. Seeing this argument, we attempt to test whether Portuguese agriculture employs sustainable practices. Table 1 displays description of the independent variables.

\begin{tabular}{|l|l|c|}
\hline & Expected Sign & Source \\
\hline$E C$ & Positive effect on $\mathrm{CO}_{2}$ & World Bank (2018) \\
\hline Crop & Positive effect on $\mathrm{CO}_{2}$ & FAO and World Bank (2018) \\
\hline Livestock & Positive effect on $\mathrm{CO}_{2}$ & FAO and World Bank (2018) \\
\hline Land & Positive effect on $\mathrm{CO}_{2}$ & FAO and World Bank (2018) \\
\hline
\end{tabular}

Source: author's elaboration

Table 1: Description of the independent variables.

The relationship between variables is discovered by Granger causality. Augmented Dickey-
Fuller test (ADF) employed to evaluate the stationarity and the adequacy of the variables used in this research. Our study also applies the ARDL model bounds test proposed by Pesaran et al. (2001), Kripfganz and Schneider (2016; 2018) to assess long-run cointegration between factors of $\mathrm{CO}_{2}$ emission.

Equation (3) presents the ARDL model based on Ozturk and Acaravci (2011), Sarkodie and Owusu (2017), and Matthew et al. (2018):

$$
\begin{aligned}
& \Delta L n C O_{2}=\beta_{0}+\beta_{1} \Delta L n C O_{2 t-1}+\beta_{2} \Delta L n E C_{t-1} \\
& +\beta_{3} \Delta \text { LnCrop }_{t-1}+\beta_{4} \Delta \text { LnLivestock }{ }_{t-1} \\
& +\beta_{5} \Delta \text { LnLand }_{t-1}+\sum_{t=1}^{n} \beta_{1} \Delta \operatorname{LnCO}{ }_{2 t-1} \\
& +\sum_{t=0}^{n} \beta_{2} \Delta \operatorname{LnEC}_{t-1}+\sum^{n}{ }_{t=0} \beta_{3} \Delta \text { LnCrop }{ }_{t-1} \\
& +\sum^{n}{ }_{t=0} \beta_{4} \Delta \text { LnLivestock }_{t-1}+\sum^{n}{ }_{t=0} \beta_{5} \Delta \text { LnLand }_{t-1} \\
& +\gamma E C M_{t-1}+e
\end{aligned}
$$

In equation 3, all variables are expressed in logarithm form.

$\Delta$ represents the change in operator;

$E C M_{t-1}$ denotes the error correction term;

$\gamma$ illustrates the adjustment of short and long run.

According to the literature, the ARDL model assumes two conditions (Pesaran et al., 2001, Shahbaz et al., 2015, and Matthew et al., 2018):

$H_{0}: \beta_{0}=\beta_{1}=\beta_{2}=\beta_{3}=\beta_{4}=\beta_{5}$, no relationship exists in the long-run.

$H_{1}: \beta_{0} \neq \beta_{1} \neq \beta_{2} \neq \beta_{3} \neq \beta_{4} \neq \beta_{5}$, a long-run relationship exists.

\section{Results and discussion}

Results are calculated by STATA software. Table 2 presents the correlation for all variables used in this investigation. The correlation coefficients indicate that independent variables are associated positively with carbon dioxide emissions.

Table 3 reports the unit root test using Augmented Dickey-Fuller (ADF) with trend. Thus, the null hypothesis of the test indicates that variables have unit root (are stationary alternatively). According to the result of unit root tests, all variables are stationary. Moreover, the rejection of hypothesis

\begin{tabular}{|l|c|c|c|c|c|}
\hline & $\mathrm{LnCO}_{2}$ & LnEC & LnCrop & LnLivestock & LnLand \\
\hline $\mathrm{LnCO}_{2}$ & 1.000 & & & & \\
\hline LnEC & 0.975 & 1.000 & & & \\
\hline LnCrop & 0.934 & 0.846 & 1.000 & & \\
\hline LnLivestock & 0.555 & 0.713 & 0.262 & 1.000 & \\
\hline LnLand & 0.957 & 0.875 & 0.991 & 0.298 & 1.000 \\
\hline \multicolumn{5}{|l|}{ Observations $=55$}
\end{tabular}

Source: author's elaboration based on World Bank database (2018).

Table 2: Correlation between variables. 
demonstrates that the time series are integrated into this research.

\begin{tabular}{|l|c|c|}
\hline Augmented Dickey-Fuller test & \multicolumn{2}{|c|}{ ADF at Level } \\
\hline Variables & Statistic & P-value \\
\hline $\mathrm{LnCO}_{2}$ & $-6.356^{* * *}$ & 0.000 \\
\hline LnEC & $-6.287^{* * *}$ & 0.000 \\
\hline LnCrop & $-6.568^{* * *}$ & 0.000 \\
\hline LnLivestock & $-6.271^{* * *}$ & 0.000 \\
\hline LnLand & $-6.540^{* * *}$ & 0.000 \\
\hline
\end{tabular}

Note: $* * *$ Statistically significant at $1 \%$

Source: author's elaboration based on World Bank database (2018)

Table 3: Unit root test: ADF (Augmented Dickey-Fuller) with the trend.

At the first step, we present the estimates obtained from the ARIMA method (Table 4) and the Newey-West Standard Errors regression (Table 5). The coefficient of energy consumption $(E C)$ is statistically significant at $1 \%$ level and have a positive effect on $\mathrm{CO}_{2}$ emissions $\left(H_{1}\right)$. This result is supported by previous studies of Ozturk and Acaravci (2011), Shahbaz and Leitão (2013), Kais and Mbarek (2015), Tan and Tan (2018) confirm that energy consumption, in particular, fossil energies (non-renewables) increases carbon dioxide emissions and consequently accentuates climate change. Moreover, we can affirm that the results are according to the literature and with the hypothesis formulated.

\begin{tabular}{|l|c|}
\hline \multicolumn{1}{|c|}{ Variables } & Coef. \\
\hline LnEC & $1.000^{* * *}(0.000)$ \\
\hline LnCrop & $-0.020(0.766)$ \\
\hline LnLivestock & $0.001^{*}(0.064)$ \\
\hline LnLand & $0.315^{* *}(0.021)$ \\
\hline C & $-0.010^{*}(0.05)$ \\
\hline Observations & 53 \\
\hline AR & $0.604[0.931]$ \\
\hline MA & $-0.306[0.657]$ \\
\hline Sigma & $0.01[0.000]$ \\
\hline Wald Chi ${ }^{2}(4)$ & 630.25 \\
\hline Prob $>$ Chi $^{2}$ & 0.000 \\
\hline Log Likelihood $^{2}$ & 132.2685 \\
\hline
\end{tabular}

Note: $* * *$ ignificant at $1 \%, * *$ at $5 \%$, and $* 10 \%$

Source: author's elaboration based on World Bank database (2018)

Table 4: Agricultural Factors and Energy Consumption with ARIMA model.

The coefficients of the livestock production index (LnLivestock), along with agricultural land use (LnLand) induce a positive impact on carbon dioxide emissions $\left(\mathrm{H}_{2}\right)$. These results are in line with Hongdou et al. (2018), Sarkodie and Owusu (2017), and Khan et al. (2018).
The econometric results also allow to infer that serial correlation test (AR) is 0.931, and Sigma (white-noise) is statistically significant. When we apply the Newey-West Standard Errors regression (Table 5), the results are slightly different, but as the previous estimator, energy consumption $(L n E C)$, livestock production index (LnLivestock), and agricultural land (LnLand) follow the same tendency, i.e. proving that these independent variables increase carbon dioxide emissions. Except for the coefficient of crop production index ( $\mathrm{LnCrop}$ ) that shows a negative association with $\mathrm{CO}_{2}$ emissions, in this case, the results obtained are in contrast with the expectations.

\begin{tabular}{|l|c|}
\hline \multicolumn{1}{|c|}{ Variables } & Coef. \\
\hline LnEC & $0.405^{* * *}(0.000)$ \\
\hline LnCrop & $-0.348^{* *}(0.021)$ \\
\hline LnLivestock & $0.004 * * *(0.000)$ \\
\hline LnLand & $0.802^{* * *}(0.000)$ \\
\hline C & $-0.137 * * *(0.000)$ \\
\hline Observations & 55 \\
\hline F(4,50) & 174330.96 \\
\hline Prob $>F$ & 0.000 \\
\hline
\end{tabular}

Note: *** ignificant at $1 \%, * *$ at $5 \%$,

Source: author's elaboration based on World Bank database (2018)

Table 5: Agricultural Factors and Energy Consumption with Newey-West Standard Errors regression.

Table 6 presents the results using ARDL model. The estimator permits to consider the short and long-run effects of components. The adjustment coefficient or error correction coefficient [ADJCO2(-1)] demonstrates that there is a longrun relationship between variables. The lagged variable of $\mathrm{CO}_{2}$ emissions is statistically significant at $1 \%$ level. In the long run, the coefficient of carbon dioxide emissions presents a negative sign, showing that $\mathrm{CO}_{2}$ emissions decrease over time in Portugal. Sarkodie and Owusu (2017), Hongdou et al. (2018), and Kais and Mbarek (2017) also found a negative tendency of $\mathrm{CO} 2$ emissions. The empirical studies highlight the importance of dynamic models, allowing us to confront the short and long-run effects. A dynamic analysis indicates that carbon dioxide emissions tend to decline in the long run. We observe that countries are increasingly aware of the importance of reducing carbon dioxide emissions and polluting activities.

The estimated coefficients of energy consumption (LnEC), livestock production (LnLivestock), and agricultural land (LnLand) present a positive impact on $\mathrm{CO}_{2}$ emissions in the long run (LR). The coefficients of livestock production (LnLivestock), and agricultural land (LnLand) 
are statistically significant at $1 \%$ level. Hongdou et al. (2018), Beşer and Beşer (2017), Sarkodie and Owusu (2017) support our results showing that animal husbandry and agricultural production stimulate climate change and greenhouse effects.

\begin{tabular}{|c|c|}
\hline Variables & Coef. \\
\hline ADJCO2 (-1) & $-0.533 * * *(0.000)$ \\
\hline \multicolumn{2}{|l|}{ Long Run (LR) } \\
\hline $\operatorname{LnEC}$ & $0.266^{*}(0.061)$ \\
\hline LnCrop & $-0.548 * * *(0.000)$ \\
\hline LnLivestock & $0.008 * * *(0.000)$ \\
\hline LnLand & $3.946 * * *(0.000)$ \\
\hline \multicolumn{2}{|l|}{ Short Run (SR) } \\
\hline ECD1 & $1.315 * * *(0.000)$ \\
\hline LD & $0.801 * *(0.021)$ \\
\hline L2D & $0.273(0.342)$ \\
\hline L3D & $0.928 * * *(0.004)$ \\
\hline LnCropD $D_{1}$ & $0.212 *(0.090)$ \\
\hline LD & $0.178 * *(0.020)$ \\
\hline LnLivestock & $-0.003 * *(0.023)$ \\
\hline LD & $-0.001(0.359)$ \\
\hline L2D & $-0.002 * *(0.039)$ \\
\hline L3D & $-0.002 *(0.078)$ \\
\hline LnLand $C D_{1}$ & $-1.175^{*}(0.067)$ \\
\hline LD & $-1.322 *(0.047)$ \\
\hline L2D & $-0.142(0.373)$ \\
\hline L3D & $-0.514 * * *(0.004)$ \\
\hline $\mathrm{C}$ & $-7.551 * * *(0.003)$ \\
\hline Adj. $\mathrm{R}^{2}$ & 0.612 \\
\hline
\end{tabular}

Note: $* * *$ ignificant at $1 \%, * *$ at $5 \%$, and $* 10 \%$, and $* 10 \%$ LD represenbts Lag

Source: author's elaboration based on World Bank database (2018)

Table 6: Agricultural Factors and Energy Consumption

with Autoregressive and Distributed Lag (ARDL) model.

In the long run, the variable of crop production index is statistically significant at $1 \%$ level with a negative effect on $\mathrm{CO}_{2}$ emissions. However, in short-run (SR), the crop production index (LnCrop) indicates a positive impact on $\mathrm{CO}_{2}$ emissions, this result was supported by previous studies such as Ullah et al. (2018), Appiah et al. (2018), Sarkodie and Owusu (2017). Furthermore, the crop production index appears to increase carbon dioxide emissions thus contributing to climate change. By contrast, in the long run, it might reduce $\mathrm{CO}_{2}$ emissions.

In the short run, livestock production index, and agricultural land variables indicate a negative effect on carbon dioxide emissions. The energy consumption ( $L n E C)$ has a positive association with $\mathrm{CO}_{2}$ emissions in the short and long-run as well, confirming $\mathrm{H}_{1}$ and showing that fossil energy use stimulates climate change as suggested by Kais and Mbarek (2017), Beşer and Beşer (2017), and Leitão (2015).

Table 7 allows evaluating the long-run cointegration between the variables used in this research. We apply the ARDL bounds test established by Persaran and Shin (1999), Kripfganz and Schneider (2016, 2018). Considering the results, we can infer that the variables are cointegrated in long-run, i.e., there is a relationship (a common trend) between dependent and explanatory variables. We can also complement this information with Table 8 , where the stability of the model is evaluated.

Table 8 shows the diagnostic of ARDL model. According to the results, the model is stable, i.e., no serial correlation based on the statistics of Durbin-Watson (2.073) and Breusch-Godfrey Lagrange Multiplayer (LM) test (0.595). The White test (0.431) points out that the assumption of homoscedasticity can be accepted.

\begin{tabular}{|c|c|c|c|c|c|c|c|c|}
\hline \multicolumn{9}{|c|}{ Pesaran, Shin, and Smith (2001) bounds test } \\
\hline \multicolumn{9}{|c|}{$\begin{array}{l}F=4.153 \\
t=-4.278\end{array}$} \\
\hline \multicolumn{9}{|c|}{ sample (4 variables, 47 observations, 14 short-run coefficients) } \\
\hline \multicolumn{9}{|c|}{ Kripfganz and Schneider (2018) critical values and approximate p-values } \\
\hline & \multicolumn{2}{|c|}{$10 \%$} & \multicolumn{2}{|c|}{$5 \%$} & \multicolumn{2}{|c|}{$1 \%$} & \multicolumn{2}{|c|}{ p-value } \\
\hline & $\mathrm{I}(0)$ & $\mathrm{I}(1)$ & $\mathrm{I}(0)$ & $\mathrm{I}(1)$ & $\mathrm{I}(0)$ & $\mathrm{I}(1)$ & $\mathrm{I}(0)$ & $\mathrm{I}(1)$ \\
\hline $\mathrm{F}$ & 2.501 & 3.909 & 3.041 & 4.651 & 4.328 & 6.407 & 0.012 & 0.080 \\
\hline $\mathrm{T}$ & -2.435 & -3.541 & -2.802 & -3.970 & -3.547 & -4.835 & 0.002 & 0.029 \\
\hline
\end{tabular}

Source: author's elaboration based on World Bank database (2018)

Table 7: Agricultural Factors and Energy Consumption with ARDL: bounds test. 
Durbin-Watson d-statistic

$(20,47)=2.073539$

Breusch-Godfrey LM test for autocorrelation [H0: no serial correlation]

Prob $>\mathrm{chi}^{2}=0.5955$

White's test for Ho: homoscedasticity

$\operatorname{chi}^{2}(46)=47.00$

Prob $>\mathrm{chi}^{2}=0.4313$

Source: author's elaboration based on World Bank database (2018)

Table 8: Diagnostic of ARDL model.

Table 9 shows the results of the Granger causality. There is bidirectional causality between carbon dioxide emissions $\left(\mathrm{CO}_{2}\right)$ and crop production index (Crop). The results confirm that crop production causes climate change in accordance with the previous studies of Appiah et al. (2018), Hongdou et al. (2018), Ullah et al. (2017), and Sarkodie and Owusu (2017. In this context, Appiah et al. (2018) using the Pooled Mean Group (PMG) causality estimator revealed a positive relationship between crop production and carbon dioxide emissions. Moreover, Hongdou et al. (2018:24497) found a positive value (2.439) while
Sarkodie and Owusu (2017:199) also suggested a positive association (5.8990) with climate change.

There is a unidirectional causality between $\mathrm{CO}_{2}$ emissions and livestock production index and it holds for agricultural land. Consequently, land use change (such as deforestation, soil erosion, arable land) without paying special attention to the concept of sustainable development, i.e., intensive fertilizer uses, and machine-intensive farming significantly stimulates carbon dioxide emissions.

We also observe that there is a unidirectional causality between energy consumption $(E C)$, crop production index (Crop), and agricultural land (Land). In conclusion, agricultural land has a unidirectional causality with crop production index indicating that crop production needs more agricultural land area. Finally, the livestock production induces a unidirectional causality with agricultural land suggesting the significant role of animal farming and land intensive meat production through $\mathrm{CO}_{2}$ emission on climate change.

\begin{tabular}{|c|c|c|c|}
\hline Null Hypothesis & $\mathrm{Chi}^{2}$ & Df & Prob $>$ chi $^{2}$ \\
\hline $\mathrm{LnCO}_{2}$ does not Granger Cause LnEC & $10.837 * * *$ & 2 & 0.004 \\
\hline LnEC does not Granger Cause $\mathrm{LnCO}_{2}$ & 3.6552 & 2 & 0.161 \\
\hline $\mathrm{LnCO}_{2}$ does not Granger Cause LnCrop & $8.2834 * *$ & 2 & 0.016 \\
\hline LnCrop does not Granger Cause $\mathrm{LnCO}_{2}$ & $6.0277^{* *}$ & 2 & 0.049 \\
\hline $\mathrm{LnCO}_{2}$ does not Granger Cause LnLivestock & $14.867 * * *$ & 2 & 0.001 \\
\hline LnLivestock does not Granger Cause $\mathrm{LnCO}_{2}$ & 0.404 & 2 & 0.817 \\
\hline $\mathrm{LnCO}_{2}$ does not Granger Cause LnLand & $133.46 * * *$ & 2 & 0.000 \\
\hline LnLand does not Granger Cause $\mathrm{LnCO}_{2}$ & 0.833 & 2 & 0.659 \\
\hline LnEC does not Granger Cause LnCrop & $6.3557 * *$ & 2 & 0.042 \\
\hline LnCrop does not Granger Cause LnEC & 0.784 & 2 & 0.676 \\
\hline LnEC does not Granger Cause LnLivestock & 1.6207 & 2 & 0.445 \\
\hline LnLivestock does not Granger Cause LnEC & 1.652 & 2 & 0.438 \\
\hline LnEC does not Granger Cause LnLand & $314.05^{* * *}$ & 2 & 0.000 \\
\hline LnLand does not Granger Cause LnEC & 3.1875 & 2 & 0.203 \\
\hline LnCrop does not Granger Cause LnLivestock & 3.699 & 2 & 0.157 \\
\hline LnLivestock does not Granger Cause LnCrop & 0.244 & 2 & 0.885 \\
\hline LnCrop does not Granger Cause LnLand & 2.3267 & 2 & 0.312 \\
\hline LnLand does not Granger Cause LnCrop & $23.393 * * *$ & 2 & 0.000 \\
\hline LnLivestock does not Granger Cause LnLand & $56.102 * * *$ & 2 & 0.000 \\
\hline LnLand does not Granger Cause LnLivestock & 2.7939 & 2 & 0.247 \\
\hline
\end{tabular}

Note: $* * *$ ignificant at $1 \%, * *$ at $5 \%$, and $* 10 \%$, and $* 10 \%$

Source: author's elaboration based on World Bank database (2018)

Table 9: Agricultural Factors and Energy Consumption with Granger Causality. 
Table 10 exhibits the Johansen cointegration test using the criteria of trace methods. Based on the test, the hypothesis of no cointegration is rejected (rejection of the hypothesis at $0.05 \%$ level).

\begin{tabular}{|c|c|c|c|}
\hline & Trace & 0.05 & \\
\hline Eigenvalue & Statistic & Critical Value & Prob.** \\
\hline 0.458575 & 81.72113 & 69.81889 & 0.0042 \\
\hline 0.323034 & 49.20290 & 47.85613 & 0.0371 \\
\hline 0.301677 & 28.52577 & 29.79707 & 0.0695 \\
\hline 0.145174 & 9.494848 & 15.49471 & 0.3216 \\
\hline 0.022044 & 1.181417 & 3.841466 & 0.2771 \\
\hline
\end{tabular}

Note: Trace test indicates 2 cointegration equations at 0.05 level. Source: author's elaboration based on World Bank database (2018)

Table 10: Johansen cointegration test (Trace methods).

\section{Conclusion}

The article investigated the short and the longrun relationships between Portuguese carbon dioxide emissions and agricultural activity, energy consumption, using ARDL, ARIMA model, Newey-West regression and Granger causality for the period of 1960-2015.

The Augmented Dickey-Fuller (ADF) unit root test demonstrated that the variables used in this investigation are stationary. Employing the ARDL model, the lagged variable of $\mathrm{CO}_{2}$ (adjustment coefficient) presented a negative sign with statistically significance, i.e., in the longrun, we observed that carbon dioxide emissions decreased in Portugal in line with previous studies (Sarkodie and Owusu 2017; Hongdou et al., 2018; and Kais and Mbarek, 2017). The agricultural activity measured by three variables (crop production index, livestock production index, and agricultural land use) revealed a long-run causal relation with $\mathrm{CO}_{2}$, i.e., agricultural activity significantly affects climate change in Portugal. Waheed et al. (2018), Jebli and Youssef (2017), and Appiah et al. (2018) also confirmed a positive association between these variables.

Furthermore, our results indicate that energy consumption had a positive impact on Portuguese
$\mathrm{CO}_{2}$ emissions when we apply the ARDL model in the short and long-run supporting the result of Kais and Mbarek (2015), Tan and Tan (2018). Moreover, the econometric results verified with Newey-West regression offers some similarities with the autoregressive distributed lag model. Thus, energy consumption has a positive correlation with carbon dioxide emissions.

The findings of the research allow evaluating the different agricultural sectors and the impacts of energy efficiency on climate change measured by carbon dioxide emissions. The results suggest that increasing agricultural production and energy efficiency associated with economic growth but it does increase carbon dioxide emissions too. Since these factors stimulate global warming, environmental degradation and pose a risk for human health, it emphasizes the importance of the topic in the economics literature.

In line with international empirical literature such as Edoja et al. (2016), Sarkodie, and Owusu, (2017), the data published by the EPA (2018) and Eurostat (2018), we attempt to provide some policy recommendations for Portugal. The Portuguese agriculture needs to take measures to achieve a higher level of sustainable development, intending to reduce the effect of animal husbandry and intensive crop production practice to diminish $\mathrm{CO}_{2}$ emission. Although organic farming has higher production costs, it is an alternative way to encourage sustainable agricultural practices by reducing environmental pollution in agriculture. Furthermore, substituting beef meat with another livestock sector (e.g. pork or poultry) possibly will reduce the effects of agriculture on climate change (Desjardins et al., 2014). Besides, we also suggest changes in agricultural practices e.g. the reduction of pesticides and fertilizers with special attention to ammonia levels as reported by EPA (2018), Eurostat (2018).

Regarding the directions for future research, it seems interesting to extend the study to the EuroMediterranean countries. Moreover, we suppose that it will be exciting to test this group of countries with static and dynamic panel methods.

Corresponding authors

Jeremiás Máté Balogh, PhD, assistant professor

Corvinus University of Budapest, 8 Fövám tér, 1093 Budapest, Hungary

Phone: +3630 318-6332,E-mail: jeremias.balogh@uni-corvinus.hu

ORCID:0000-0001-9081-0071 


\section{References}

[1] Acheampong, A., O. (2018) "Economic growth, $\mathrm{CO}_{2}$ emissions and energy consumption: What causes what and where?“, Energy Economics, Vol. 74, pp. 677-692. ISSN 0140-9883. DOI 10.1016/j.eneco.2018.07.022.

[2] Appiah, K., Du, J. and Poku, J. (2018) "Causal relationship between agricultural production and carbon dioxide emissions in selected emerging economies", Environmental Science and Pollution Research, Vol. 25, pp. 24764-24777. E-ISSN 1614-7499, ISSN 0944-1344. DOI $10.1007 / \mathrm{s} 11356-018-2523-\mathrm{z}$.

[3] Balogh, J. M. and Jambor, A. (2017) "Determinants of $\mathrm{CO}_{2}$ emission: A global evidence", International Journal of Energy Economics and Policy, Vol. 75, No. 5, pp. 217-226. ISSN 2146-4553

[4] Beşer, M. K. and Beşer, B. H. (2017) “The relationship between energy consumption, $\mathrm{CO}_{2}$ emissions and GDP per capita: A revisit of evidence from Turkey", The Journal of Operations Research, Statistics, Econometrics and Management Information Systems, Vol. 5, No 3, pp. 353-367. E-ISSN 2148-2225. DOI 10.17093/alphanumeric.353957.

[5] Desjardins, R. L., Worth, D. E., Vergé, X. P. C., VanderZaag, A., Janzen, H., Kroebel, R. and Dyer, J. A. (2014) "Carbon Footprint of Agricultural Products - A Measure of the Impact of Agricultural Production on Climate Change“, Agriculture and agro-food Canada [Online]. Available: http://www.wamis.org/agm/meetings/teco14/S5-Desjardins.pdf [Accessed: 10 Feb, 2019].

[6] Edoja, P. E., Aye, G. C. and Abu, O. (2016) "Dynamic relationship among $\mathrm{CO}_{2}$ emission, agricultural productivity and food security in Nigeria“, Cogent Economics and Finance, Vol. 4, pp. 1-13. E-ISSN 2332-2039. DOI 10.1080/23322039.2016.1204809.

[7] Eurostat (2018) "European Union's Agriculture, Greenhouse gas emission statistics" [Online]. Available: https:/ec.europa.eu/eurostat/statistics-explained/index.php/Archive:Agriculture_greenhouse_gas_emission_statistics[Accessed: 15 Jan, 2019].

[8] EPA (2018) "United States Environmental Protection Agency. Greenhouse gas emission data". [Online]. Available: https:/www.epa.gov/ghgemissions/global-greenhouse-gas-emissions-data [Accessed: 18 Jan. 2019].

[9] Food and Agriculture Organization (FAO) Data [Online]. Available: http://www.fao.org/faostat/ en/\#home [Accessed: 18 Jan, 2019].

[10] Hongdou, L., Shiping, L. and Hao, L. (2018) "Existing agricultural ecosystem in China leads to environmental pollution: an econometric approach", Environmental Science and Pollution Research, Vol. 25, pp. 24488-24499. E-ISSN 1614-7499, ISSN 0944-1344. DOI 10.1007/s11356-018-2461-9.

[11] Jebli, M., B. and Youssef, S. B. (2017) "The role of renewable energy and agriculture in reducing $\mathrm{CO}_{2}$ emissions: Evidence for North Africa countries“, Ecological Indicators, Vol. 74, pp. 295-301. ISSN 1470-160X. DOI 10.1016/j.ecolind.2016.11.032.

[12] Kais, S. and Mbarek, M. B. (2017) "Dynamic relationship between $\mathrm{CO}_{2}$ emissions, energy consumption and economic growth in three North African countries", International Journal of Sustainable Energy, Vol. 36, No. 9, pp. 840-854. E-ISSN 1478-646X. ISSN 1478-645. DOI 10.1080/14786451.2015.1102910.

[13] Khan, M. T. I., Ali, Q. and Ashfaq, M. (2018) "The nexus between greenhouse gas emission, electricity production, renewable energy and agriculture in Pakistan,“ Renewable Energy, Vol. 118, pp. 437-451. ISSN 0960-1481. DOI 10.1016/j.renene.2017.11.043.

[14] Kripfganz, S. and Schneider, D. C. (2018) "Response surface regressions for critical value bounds and approximate p-values in equilibrium correction models", Manuscript, University of Exeter and Max Planck Institute for Demographic Research. [Online]. Available: www.kripfganz.de/research/ Kripfganz_Schneider_ec.html [Accessed: 8 Feb, 2019]. 
[15] Kripfganz, S. and Schneider, D. C. (2016) “Ardl: Stata module to estimate autoregressive distributed lag models", Presented July 29, 2016, at the Stata Conference, Chicago [Online]. Available: Available: fmwww.bc.edu/repec/chic2016/chicago16_kripfganz.pdf [Accessed: 8 Feb, 2019].

[16] Leitão, N. C. (2015) "Energy Consumption and Foreign Direct Investment: A Panel Data Analysis for Portugal“", International Journal of Energy Economics and Policy, Vol. 5, No. 1, pp. 138-147. ISSN 2146-4553.

[17] Mara, F. P. O. (2011) "The significance of livestock as a contributor to global greenhouse gas emissions today and in the near future", Animal Feed Science and Technology, Vol. 166-167, pp. 7-15. ISSN 0377-8401. DOI 10.1016/j.anifeedsci.2011.04.074.

[18] Marques, A. C., Fuinhas, J. A. and Pais, D. F. (2018) "Economic growth, sustainable development and food consumption: Evidence across different income groups of countries", Journal of Cleaner Production, Vol. 196, pp. 245-258. ISSN 0959-6526. DOI 10.1016/j.jclepro.2018.06.011.

[19] Mahmood, H. and Alkhateeb, T. T. Y. (2017) "Trade and Environment Nexus in Saudi Arabia: An Environmental Kuznets Curve Hypothesis“, International Journal of Energy Economics and Policy, Vol. 7, No. 5, pp. 291-295. ISSN 2146-4553.

[20] Matthew O., Osabohien, R., Fasina, F. and Fasina, A. (2018) "Greenhouse Gas Emissions and Health Outcomes in Nigeria: Empirical Insight from ARDL Technique", International Journal of Energy Economics and Policy, Vol. 8, No. 3, pp. 43-50. ISSN 2146-4553.

[21] Mourão, P. R. and Domingues Martinho, V. (2017) "Portuguese agriculture and the evolution of greenhouse gas emissions - can vegetables control livestock emissions?", Environmental Science and Pollution Research, Vol. 24, No. 19, pp. 16107-16119. E-ISSN 1614-7499, ISSN 0944-1344. DOI 10.1007/s11356-017-9257-1.

[22] Och, M. (2017) "Empirical Investigation of the Environmental Kuznets Curve Hypothesis for Nitrous Oxide Emissions for Mongolia“, International Journal of Energy Economics and Policy, Vol. 7, No. 1, pp. 117-128. ISSN 2146-4553.

[23] Ozturk, I. and Acaravci, A. (2011) "Electricity Consumption and real GDP Causality Nexus: Evidence from ARDL Bounds Testing Approach for 11 MENA Countries", Applied Energy, Vol. 88, No. 8, pp. 2885-2892. ISSN 0306-2619. DOI 10.1016/j.apenergy.2011.01.065.

[24] Pesaran, M. H., Shin, Y. and Smith, R. J. (2001) "Bounds testing approaches to the analysis of level relationships", Journal of Applied Econometrics, Vol. 16, pp. 289-326. ISSN 1099-1255. DOI 10.1002/jae.616.

[25] Pesaran, M. H. and Shin, Y. (1999) "An autoregressive distributed lag modeling approach to cointegration analysis", In: Strom, S. (editor) "Econometrics and Economic Theory in the $20^{\text {th }}$ Century: The Ragnar Frisch Centennial Symposium". Ch. 11. Cambridge: Cambridge University Press. E-ISBN 9781139052221.

[26] PIA (2013) "Portuguese Environmental Agency Portuguese National Invert Report on Greenhouse Gases 1990-2011“, Submitted under the United Nations Frame- work convention on Climate change and the Kyoto.

[27] Ritchie, H. (2017) "How much of the world's land would we need in order to feed the global population with the average diet of a given country? Our World in Data". October 3, 2017 [Online]. Available: https://ourworldindata.org/agricultural-land-by-global-diets [Accessed: 20 Jan. 2019].

[28] Shahbaz, M., Dube, S., Ozturk, I. and Jali, A. (2015) "Testing the environmental Kuznets curve hypothesis in Portugal“", International Journal of Energy Economics and Policy, Vol. 5, No. 2, pp. 475- 481. ISSN 2146-4553.

[29] Shahbaz, M., Hye, A. M. Q, Tiwari, A. K. and Leitão, N. C. (2013) "Economic growth, energy consumption, financial development, international trade and $\mathrm{CO}_{2}$ emissions in Indonesia", Renewable and Sustainable Energy Reviews, Vol. 25, pp. 109-121. ISSN 1364-0321. DOI 10.1016/j.rser.2013.04.009. 
[30] Shahbaz, M. and Leitão, N. C. (2013) "Portuguese carbon dioxide emissions and economic growth: A time series analysis“, Bulletin of Energy Economics, Vol. 1, No. 1, pp. 1-7.

[31] Sarkodie, S. A. and Owusu, P. A. (2017) "The relationship between carbon dioxide, crop and food production index in Ghana: By estimating the long-run elasticities and variance decomposition", Environmental Engineering Research, Vol. 22, No. 2, pp. 193-202. E-ISSN 2005-968X, ISSN 1226-1025. DOI 10.4491/eer.2016.135.

[32] Statista (2018) "Carbon Dioxide emissions in Portugal from 2000-2017 (in million metric tons of $\left.\mathrm{CO}_{2}\right)^{\text {“. }}$ [Online]. Available: https://www.statista.com/statistics/449812/co2-emissions-portugal/ [Accessed: 15 Jan. 2019].

[33] Tan, C. C. and Tan, S. (2018) "Energy Consumption, $\mathrm{CO}_{2}$ Emissions and Economic Growth: A Causality Analysis for Malaysian Industrial Sector", International Journal of Energy Economics and Policy, Vol. 8, No. 4, pp. 254-258. ISSN 2146-4553.

[34] Torres, P., Ferreira, J. Monteiro, A., Costa, S., Pereira, M. C., Madureira, J., Mendes, A. and Teixeira, J. P. (2018) "Air pollution: A public health approach for Portugal", Science of The Total Environment, Vol. 643, pp. 1041-1053. ISSN 0048-9697. DOI 10.1016/j.scitotenv.2018.06.281.

[35] Ullah, A., Khan, D., Khan I. and Zheng, S. (2018) "Does agricultural ecosystem cause environmental pollution in Pakistan? Promise and menace“, Environmental Science and Pollution Research, Vol. 25, No. 2, pp. 1-18. E-ISSN 1614-7499, ISSN 0944-1344. DOI 10.1007/s11356-018-1530-4.

[36] Waheed R., Chang, D., Sarwar, S. and Chen, W. (2018) "Forest, agriculture, renewable energy, and $\mathrm{CO}_{2}$ emission", Journal of Cleaner Production, Vol. 172, pp. 4231-4238. DOI 10.1016/j.jclepro.2017.10.287.

[37] World Bank (2018) "World Development Indicators' data". [Online]. Available: http://datatopics. worldbank.org/world-development-indicators/ [Accessed: 20 Feb. 2019]. 